\title{
ANALISIS USABILITY APLIKASI SISTEM INFORMASI DESTINASI WISATA PULAU AMBON BERBASIS ANDROID
}

\author{
Sri Widyanti Ginting*1, I Made Sudarma ${ }^{2}$ \\ ${ }^{1,2}$ Universitas Udayana, Denpasar, Bali \\ E-mail ${ }^{1}$ :widya.unud2018@gmail.com, ${ }^{2}$ imasudarma@gmail.com \\ *Penulis Korespondensi
}

(Naskah masuk: 26 November 2019, diterima untuk diterbitkan: 07 Oktober 2020)

\begin{abstract}
Abstrak
Penelitian bertujuan untuk mengetahui sejauh mana suatu aplikasi Sistem Informasi Wisata di Pulau Ambon dapat diterima masyarakat dan dan seberapa besar tingkat kepuasan masyarakat akan adanya Sistem Informasi yang dibuat. Penulis dalam hal ini membuat suatu aplikasi untuk melihat persepsi pengguna terhadap aplikasi sistem informasi pariwisata di Kota Ambon berbasis Android dengan mengandalkan fitur yang dapat diakses dengan mudah dan tampilan yang sederhana, Selanjutnya untuk melihat sejauh mana tingkat kebergunaan aplikasi, dilakukan pengujian usability dengan melibatkan pengguna, bagaimana pengguna menggunakan sistem serta permasalahan yang dihadapi. Pengujian dilakukan menggunakan kuisioner untuk mengukur kepuasan pengguna dan untuk mengetahui opini pengguna terhadap aplikasi yang digunakan. Metode yang digunakan adalah metode Waterfall, yang terdiri dari tahapan Analisis Kebutuhan, Perancangan, Implementasi dan Pengujian. Pengumpulan data dilakukan dengan menyebar kuesioner tertulis kepada 100 orang responden di beberapa spot daerah wisata. Data kuesioner yang telah diberikan kepada responden dianalisa menggunakan model skala likert. Dari diagram hasil dapat dianalisa sebagian besar responden setuju bahwa aplikasi mampu memenuhi unsur usability yakni : learnability, eficiency, memorability, errors, dan satisfaction. Sehingga dapat diambil kesimpulan bahwa aplikasi sistem informasi wisata Pulau Ambon berbasis Android mampu memberikan informasi tempat wisata, kegiatan wisata dan daftar kuliner yang bisa digunakan untuk lebih memudahkan wisatawan dalam merencanakan tujuan wisata yang diinginkan.
\end{abstract}

Kata Kunci : informasi wisata, aplikasi android, usability, analisa likert

\section{USABILITY ANALYSIS OF THE APPLICATION OF AMBON ISLAND DESTINATION TOURISM INFORMATION SYSTEM BASED ON ANDROID}

\begin{abstract}
The research aims to determine the extent of Tourism Information Systems application on Ambon Island can be accepted by the public and the level of community satisfaction with the existing information system created. The author in this case creates an application to see the user's perception of the application of Android-based tourism information systems in Ambon City by relying on features that can be easily accessed with an easy display. Furthermore, to see the extent of the usability of the application, a test is performed to view the usability testing by involving the user, how users use the system and the problems the users experienced. The test was carried out using a questionnaire to measure user satisfaction and to observe the user's opinion of the application. The method used is the Waterfall method, which consists of Requirement Analysis, Design, Implementation, and Testing. Data collection was carried out by distributing written questionnaires to 100 respondents in several tourism spots. Questionnaire data given to respondents are analyzed using a Likert scale model. From the results diagram it can be analyzed that most respondents agree that the application is able to fulfill the usability components, which is learnability, efficiency, memorability, errors, and satisfaction. So it can be concluded that the Android-based Ambon Island tourism information system application is able to provide tourist attractions, tourist activities and culinary lists that can be used by tourists to facilitate them to plan their desired tourist destinations.
\end{abstract}

Keywords: travel information, android application, usability, likert analysis 


\section{PENDAHULUAN}

Ambon adalah daerah kepulauan yang dikenal dengan sebutan "Ambon Manise" memiliki panorama yang indah dengan objek wisata alam dan budayanya yang menarik sehingga menjadi perhatian wisatawan baik Nusantara maupun mancanegara.. Menurut Dinas Pariwisata dan Kebudayaan (Disparbud) Kota Ambon, pendataan wisatawan yang dilakukan sampai pada September 2018 menunjukkan bahwa jumlah wisatawan mancanegara mencapai 11.015 orang, sementara wisatawan Nusantara sebanyak 17.228 orang. Statik menunjukkan terdapat peningkatan jumlah wisatawan dibanding tahun-tahun sebelumnya. Dan diharapkan akan terus meningkat sejalan dengan program pemerintah kota yakni "Visit Ambon 2020" (https://www.suarakarya.id. 2019)

Menurut UU. No. 10 Tahun 2009 pariwisata adalah berbagai macam kegiatan wisata dan didukung berbagai fasilitas serta layanan yang disediakan oleh masyarakat, pengusaha, pemerintah pusat dan pemerintah daerah (Ferdinandus dan Suryaningsih, 2014). Melihat perkembangan potensi pariwisata di Pulau Ambon, maka dukungan dari segala aspek perlu dilakukan. Jumlah wisatawan yang terus bertambah akan semakin terus meningkat apabila didapatkan kemudahan untuk mendapat informasi dan akses ke suatu daerah (Sudarma, 2019). Pemerintah kota Ambon, melalui dinas pariwisata sudah mulai memperkenalkan aplikasi untuk menginformasikan wisata di Ambon misalkan Ambon@Access (Ambon.go.id. 2019). Beberapa rencana Pemerintah Kota Ambon juga dibuat berkaitan dengan pengembangan sistem informasi pariwisata kota Ambon, diantaranya rencana pembuatan sistem informasi kreatif pariwisata berbasis digital ArcGis Android (Antara Maluku. 2018). Sayangnya, masyarakat baik pelaku pariwisata maupun wisatawan yang datang ke Ambon, belum terlalu memanfaatkan sarana media teknologi berbasis internet untuk mengakses pariwisata Pulau Ambon. Hal ini terlihat dari sepinya pengunjung pada web-web pariwisata Ambon yang telah dibuat. Salah satu upaya memperkenalkan wisata Pulau Ambon adalah dengan Aplikasi berbasis mobile. Dukungan teknologi mobile yang dapat dilengkapi dengan fitur-fitur informasi dan petunjuk bagi wisatawan yang berkunjung melalui perancangan aplikasi yang berisi fitur-fitur informatif tentang wisata Pulau Ambon. Untuk melihat dan menganalisis minat masyarakat akan aplikasi sistem informasi berbasis teknologi, maka penulis mencoba membuat aplikasi sistem informasi yang sederhana.

Balapour dan Sabherwal dalam penelitian studi Meta-regreasi pada web dan aplikasi seluler menunjukkan hasil bahwa informasi dan desain aplikasi mempengaruhi persepsi kegunaan pengguna. Kedua faktor ini berbeda dalam aspek yang sama-sama penting. (Balapour dan Sabherwal, 2017). Perbedaan persepsi itu mendorong penulis untuk membuat suatu aplikasi untuk melihat persepsi pengguna terhadap aplikasi sistem informasi pariwisata di Pulau Ambon berbasis Android. Dengan mengandalkan fitur yang dapat diakses dengan mudah dan tampilan yang sederhana, dapat dilihat faktor yang dapat mendukung sejauh mana wisatawan merasa aplikasi dapat membantu mereka dalam memperoleh informasi tentang keberadaan potensi wisata di Pulau Ambon.

Teknologi Android dimanfaatkan untuk membangun sistem informasi wisata kepulauan yang akan menampilkan lokasi wisata dan hal-hal lain yang berhubungan dengan destinasi wisata di Pulau Ambon. Android dikembangkan oleh perusahaan kecil di Sillicon Valley yang bernama Android,inc. Selanjutnya, Google mengambil alih sistem operasi tersebut pada tahun 2005 dan mencanangkan sebagai sistem operasi yang bersifat "Open Source." (Kadir, 2013). Android menyediakan platform terbuka bagi para pengembang untuk menciptakan berbagai macam aplikasi untuk digunakan pada piranti bergerak (Fuspita dkk, 2014). Aplikasi yang dibuat berisi fitur tentang keberadaan lokasi daerah wisata, lokasi dan jenis kuliner serta informasi lain yang berkaitan dengan destinasi wisata kepulauan di Ambon. Perancangan aplikasi memanfaatkan perangkat lunak dan keras sebagai berikut :

- Hardware :

1.) Laptop dengan spesifikasi Intel Celeron Quad Core (2,16 GHZ),4 GB DDR3 RAM, Intel HD Graphic, dan 500 GB HDD.

2.) Smartphone Android Alcatel Flash 2 dengan spesifikasi OS 5.1.1 Lollipop (64 Bit),2 GB RAM, Octa Core MTK ( 1,5 GHZ, 64 Bit), GPU Mali T720.

3.) Kabel data Smarphone

4.) Printer Canon Pixma MG2570

- Software

1.) OS Microsoft Windows 7

2.) IDE Android Studio

3.) Notepad ++

4.) Adobe Dreamweaver CS 6

5.) Adobe Photoshop CS 6 untuk perancangan desain dan icon

6.) SDK Manager

7.) Java JDK 1.8.0_71 ( Java Development Kit ) untuk platform pemrograman java dalam menyusun aplikasi dan terintegrasi dengan SDK Manager serta Eclipse ADT

8.) JRE 1.8.0_71 ( Java Runtime Environment ) untuk menjalankan aplikasi yang dibangun dengan pemrograman java.

Selanjutnya untuk membantu meningkatkan antarmuka aplikasi mobile akan dilakukan pengujian usability dengan melibatkan pengguna, agar dapat memberikan informasi langsung dari pengguna tentang bagaimana pengguna menggunakan sistem serta permasalahan yang dihadapi. Pengujian dilakukan menggunakan kuisioner untuk mengukur kepuasan pengguna dan untuk mengetahui opini pengguna terhadap aplikasi yang digunakan. Usability (kegunaan) adalah bagian dari bidang ilmu multi disiplin Human Computer Interaction (HCI) 
(Pudjoatmodjo dan Wijaya 2016). Usability berasal dari kata usable yang memiliki arti dapat digunakan dengan baik (Hilabi dan Priati, 2018). Usability atau kebergunaan mengacu pada kemudahan manusia untuk menggunakan suatu alat atau produk tertentu. Usability merupakan analisis kualitatif suatu produk, dengan memperhatikan seberapa mudah user menggunakan interface produk tersebut (Nirmala dan Liandana, 2017). Usability testing memiliki manfaat dalam mengumpulkan umpan balik secara objektif dari kegunaan seperti kepuasan pengguna maupun daari segi interface (Batmetan, 2018).

\section{METODE PENELITIAN}

Pengujian dilakukan terhadap 100 responden yang mewakili karakteristik populasi penelitian, yakni pengguna aktif perangkat mobile. Diutamakan wisatawan yang sedang serta akan melakukan perjalanan wisata ke Pulau Ambon dengan tujuan untuk mendapatkan informasi terhadap destinasi wisata yang ingin dikunjungi.

Metode yang digunakan adalah metode Waterfall, dimana pengembangan perangkat dilakukan dengan tahapan yang terdiri dari perencanaan, pemodelan, pembuatan sistem, penyebaran (Pressman, 2012).

- Tahapan Analisis Kebutuhan

Pada tahapan ini, dilakukan proyek pengumpulan data yang merupakan kebutuhan untuk membangun sistem. Dilakukan juga analisa pada lokasi penelitian, wawancara dengan para wisatawan dan melihat potensial pengembangan sistem informasi yang dapat dilakukan oleh sistem yang akan dibangun. Juga dilakukan wawancara dengan penduduk sekitar maupun para pelaku usaha yang berada disekitar lokasi wisata. Hal itu dimaksudkan untuk mengumpulkan informasi langsung dari lokasi penelitian. Selain itu dilakukan juga pengumpulan literatur berupa penelitian yang berkaitan dengan sistem. Selanjutnya untuk kebutuhan pengujian dilakukan analisa dalam pembuatan instrument pengujian usability. Instrumen disusun untuk mengetahui seberapa pemahaman dan analisa kepuasan responden terhadap aplikasi.

- Tahapan Perancangan

Pada tahapan ini dilakukan desain perancangan layar dan analisa kebutuhan tampilan. Fitur yang akan ditampilkan disesuaikan dengan hasil survey kebutuhan dilokasi wisata Pulau Ambon, agar dapat menghasilkan sistem informasi yang membantu para pengguna. Dilakukan juga pembuatan kuesioner untuk selanjutnya akan dibagikan kepada responden yang akan menguji dan menggunakan aplikasi untuk mendapatkan umpan balik sistem. Berikut gambaran struktur navigasi aplikasi dalam diagram alir.

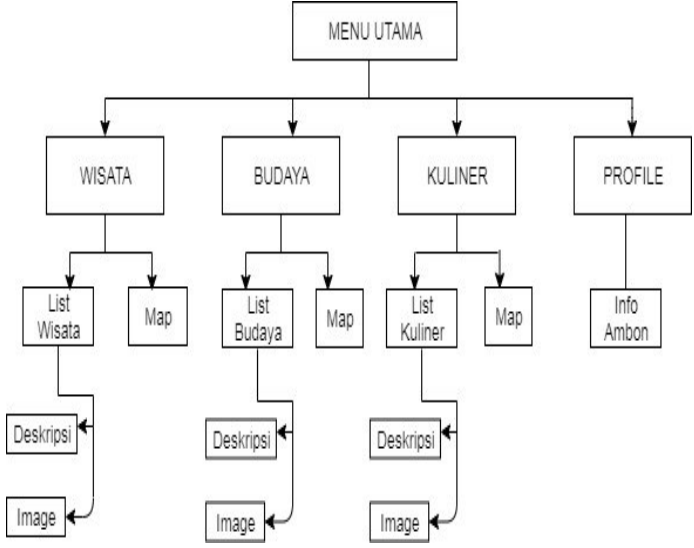

Gambar 1. Diagram alir struktur navigasi aplikasi

Pada gambar diagram alir struktur navigasi aplikasi dijelaskan bahwa tampilan aplikasi akan menunjukkan beberapa menu yang akan dapat diakses oleh pengguna. Menu-menu tersebut akan mengarahkan pengguna kepada tampilan aplikasi yang diinginkan, yang berisi informasi berupa deskripsi maupun gambar tentang wisata kepulauan Ambon.

\section{- Tahapan Implermentasi}

Pada tahapan ini, perancangan yang sudah didesain sebelumnya diwujudkan dengan melakukan pengkodean program dan singkronisasi dengan bagian lain yang terkait dengan sistem dimaksud. Pada tahapan ini, fitur-fitur lokasi wisata dan informasi sudah dapat diakses dan sistem sudah berjalan dengan baik. Perangkat yang sudah diimplementasikan akan tunjukkan kepada responden agar dapat dinilai tingkat usibility.

- Tahapan Pengujian

Pada tahapan ini dilakukan pengujian usability terhadap sistem. Pengujian dilakukan dengan memberikan kuesioner untuk kemudian diisi, kepada pengguna yang telah mencoba aplikasi yang telah dirancangbangun. Selanjutnya hasil kuesioner akan diolah dengan menggunakan analisa Likert melalui Ms. Acces dan SPSS. Diharapkann pada tahapan ini akan didapatkan hasil analisa usability system yang telah dibuat.

Tahapan penelitian digambarkan dalam Flowchart penelitian. Menurut Rini Nuraini, flowchart adalah suatu alat atau sarana yang memberikan informasi tentang langkah-langkah yang harus dilaksanakan dalam menyelesaikan suatu permasalahan untuk komputasi dengan cara mengekspresikannya ke dalam serangkaian simbolsimbol grafis khusus yang bermanfaat dalam pemecahan masalah secara sistematis dan terstruktu.(Nuraini, 2015). Dimulai dengan mengidentifikasi masalah yang ada yang berhubungan dengan solusi pemecahan bagi wisatawan yang mengalami kesulitan untuk mendapatkan informasi yang lengkap dan akurat tentang destinasi wisata di kota Ambon. 
1064 Jurnal Teknologi Informasi dan Ilmu Komputer (JTIIK), Vol. 7, No. 5, Oktober 2020, hlm. 1061-1068

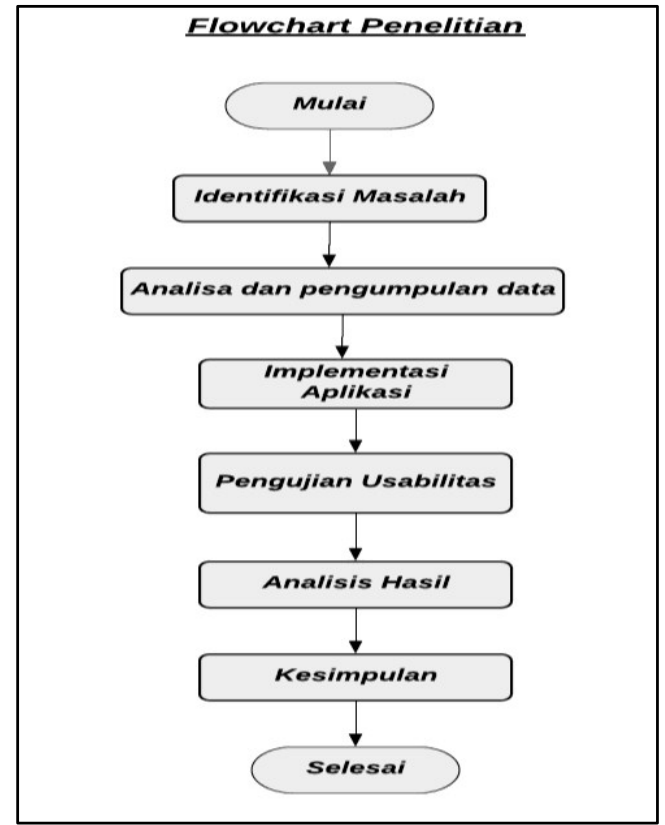

Gambar 2. Flowchart Penelitian

Selanjutnya akan dikumpulkan data mengenai dan statistik mengenai keberadaan wisatawan dan daerah wisata di Pulau Ambon. Kemudian aplikasi sistem informasi destinasi wisata Pulau Ambon berbasis android diimplementasi dan di perkenalkan kepada wisatawan yang selanjutnya akan menjadi responden untuk pengujian aplikasi. Tahapan berikut adalah pengujian aplikasi dengan menggunkan instrumen pengujian berupa kuesioner yang telah divalidasi. Dari hasil kuesioner maka dilanjutkan analisa untuk mendapatkan kesimpulan terhadap analisa usability aplikasi.

\section{HASIL DAN PEMBAHASAN}

Sebelum dilakukan analisa terhadap usability aplikasi maka terlebih dahulu aplikasi yang sudah diimplementasi diperkenalkan untuk digunakan kepada responden yang telah ditentukan. Berikut tampilan Aplikasi Sistem Informasi Wisata Kepulauan Ambon.

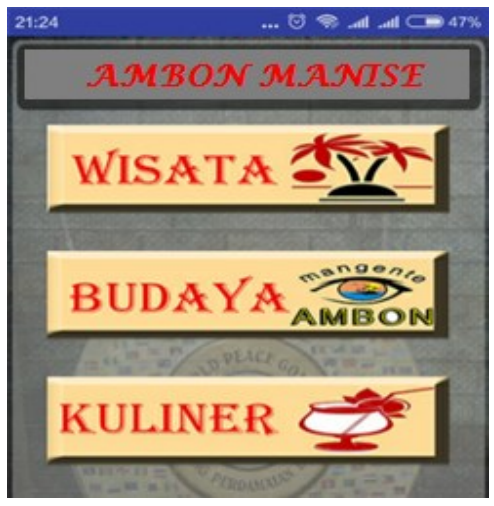

Gambar 3. Tampilan Aktifitas Utama

Di tampilan ini terdapat 3 button yang terdiri dari wisata, budaya dan kuliner, Ketika users men-tap button yang di pilih, maka akan berpindah ke activity atau halaman lainya yang dituju.

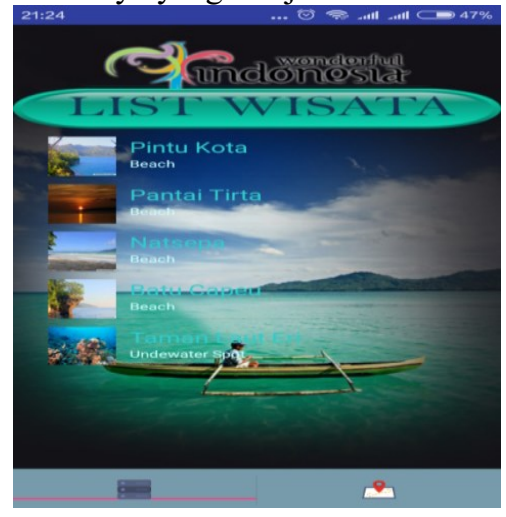

Gambar 4. Activity Wisata

Di dalam menu wisata activity, terdapat list-list tempat wisata yang ada di Pulau Ambon. Kemudian di bagian footer, 2 fungsi pemanggilan activity, yaitu activity list wisata serta maps wisata. Apabila tap salah satu list wisata, maka akan di bawa ke deskripsi wisata yang dituju dan deskripsi maps wisata yang dituju.

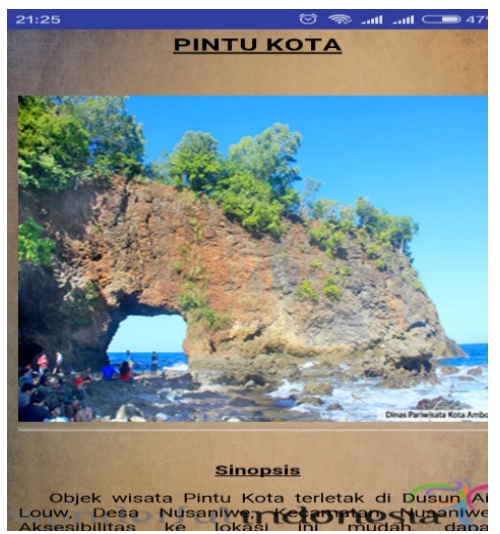

Gambar 5. List Wisata

Disini disertakan item list objek wisata, contohnya pintu kota pada aktifitas wisata. Ketika di tap item pintu kota maka akan muncul penjelasan mengenai deskripsi objek wisata itu dengan foto objek wisata dimaksud.

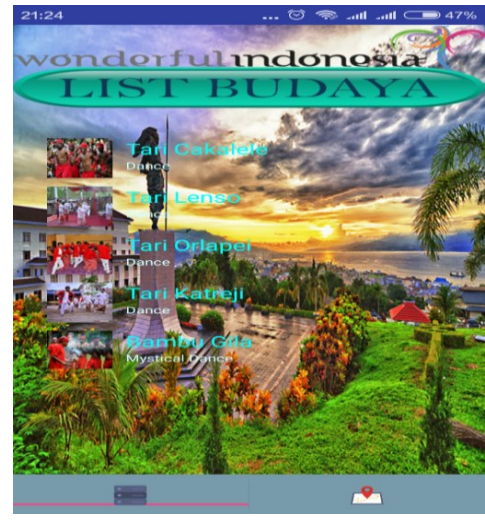

Gambar 6. Activity Budaya 
Di dalam menu budaya, terdapat list-list tempat wisata budaya yang ada di Pulau Ambon. Semuanya di panggil dalam satu fragment layar dan tergabung di tampilan dengan halaman yang sama. Apabila tap salah satu list wisata, maka akan di bawa ke deskripsi wisata yang dituju dan deskripsi maps wisata yang dituju

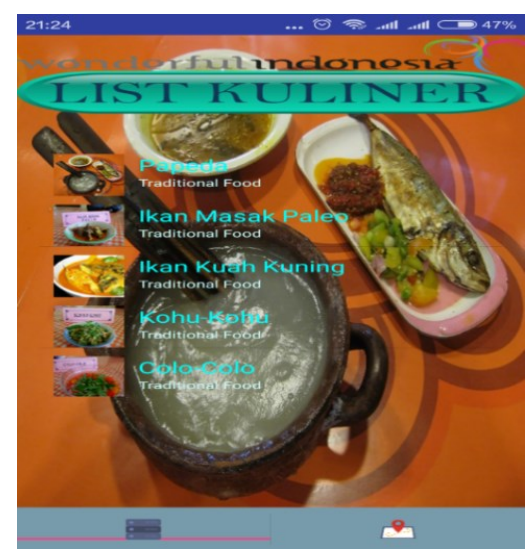

Gambar 7. Activiy Kuliner

Di dalam menu kuliner activity, terdapat list-list tempat wisata kuliner yang terkenal di Pulau Ambon. Kemudian di bagian footer, terdapat fungsi tabhost untuk membuat 2 fungsi pemanggilan activity atau halaman, yaitu activity list kuliner serta maps wisata kuliner. Semuanya di panggil dalam satu fragment layar dan tergabung di tampilan dengan halaman yang sama.

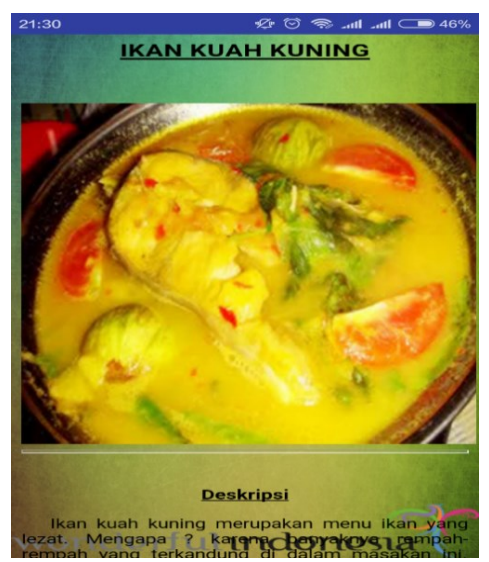

Gambar 8. Item List Kuliner

Diatas merupakan salah satu item list objek kuliner. Contohnya ikan kuah kuning pada activity kuliner, ketika di tap Item ikan kuah kuning maka akan muncul deskripsi penjelasan mengenai objek kuliner itu dengan foto objek dimaksud.

Menu ini berisi informasi yang berkaitan dengan Kota Ambon, baik berupa Sejarah, Visi-Misi Pimpinan serta Kalender Even yang diselenggarakan di kota Ambon.

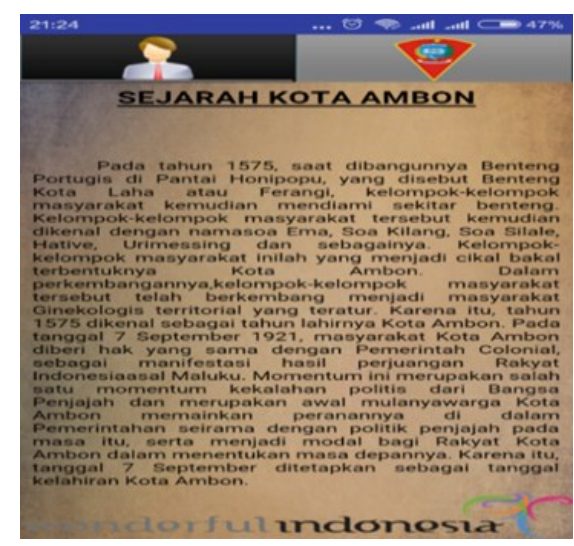

Gambar 9. Informasi

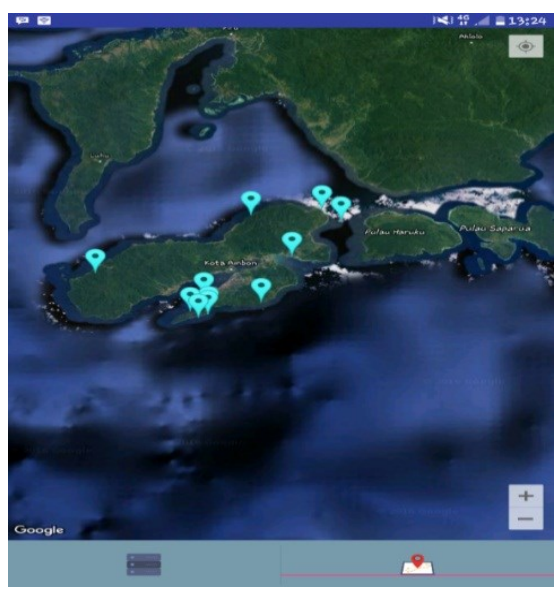

Gambar 10. Maps Wisata

Pada tampilan ini disertakan marker berdasarkan titiktitik koordinat lokasi. Ketika titik itu di tap maka akan muncul nama lokasi wisata yang dituju.

Tahapan berikutnya adalah dilakukan pengujian terhadap usability aplikasi sistem informasi pariwisata Pulau Ambon. Terlebih dahulu disiapkan instrument pengujian berupa kuesioner yang akan ditanyakan kepada responden. Responden dalam hal ini adalah wisatawan yang berasal dari berasal domestik maupun dari Mancanegara.

\section{Karakteristik Reponden}

Pengumpulan data dilakukan dengan menyebar kuesioner tertulis kepada 100 orang responden dengan rentang usia 12 - 65 tahun, di beberapa spot daerah wisata. Diantaranya, 20 untuk wilayah Natsepa, 20 untuk wilayah Liang, 20 untuk wilayah Alang, 20 untuk wilayah Ambon Kota dan 20 untuk wilayah Latuhalat. Responden mewakili pengguna mobile dan mampu mengoperasikan aplikasi berbasis Android. Responden juga diambil dari berbagai kalangan, baik professional, pegawai, ibu rumah tangga, pelajar, mahasiswa dan lain-lain, yang paham dengan perangkat mobile. 
1066 Jurnal Teknologi Informasi dan Ilmu Komputer (JTIIK), Vol. 7, No. 5, Oktober 2020, hlm. 1061-1068

Berikut adalah tabel pertanyaan dan hasil jawaban yang didapatkan dari 100 responden yang telah melakukan proses pengujian terhadap aplikasi.

\begin{tabular}{|c|c|}
\hline No. & Pertanyaan \\
\hline 1 & $\begin{array}{l}\text { Apakah aplikasi destinasi wisata pulau Ambon berbasis } \\
\text { android mudah dioperasikan? }\end{array}$ \\
\hline 2 & $\begin{array}{l}\text { Menurut anda, apakah kelengkapan menu di dalam } \\
\text { aplikasi sudah cukup? }\end{array}$ \\
\hline 3 & $\begin{array}{l}\text { Apakah aplikasi cukup membantu memberikan } \\
\text { informasi destinasi wisata di Pulau Ambon? }\end{array}$ \\
\hline 4 & $\begin{array}{l}\text { Apakah dengan mengoperasikan aplikasi cukup } \\
\text { menghemat waktu dalam mencari destinasi wisata di } \\
\text { Pulau Ambon? }\end{array}$ \\
\hline 5 & $\begin{array}{l}\text { Apakah anda dapat dengan mudah mengakses informasi } \\
\text { pada setiap menu? }\end{array}$ \\
\hline 6 & $\begin{array}{l}\text { Apakah penggunaan istilah budaya lokal pada aplikasi } \\
\text { membuat anda bingung? }\end{array}$ \\
\hline 7 & $\begin{array}{l}\text { Apakah desain, tampilan dan warna pada setiap menu } \\
\text { aplikasi membuat anda nyaman? }\end{array}$ \\
\hline 8 & $\begin{array}{l}\text { Apakah anda menemukan kesalahan-kesalahan ketika } \\
\text { mengoperasikan aplikasi? }\end{array}$ \\
\hline 9 & $\begin{array}{l}\text { Apakah secara keseluruhan anda puas menggunakan } \\
\text { aplikasi yang dimaksud? }\end{array}$ \\
\hline 10 & $\begin{array}{l}\text { Apakah anda akan merekomendasikan aplikasi destinasi } \\
\text { wisata pulau Ambon kepada rekan dan kerabat anda? }\end{array}$ \\
\hline
\end{tabular}

Tabel 1 berisi daftar pertanyaan yang akan ditanyakan pada responden . Pertanyaan yang disusun berdasarkan analisa dan literatur yang dipelajari sebelumnya, sehingga diharapkan respon pengguna bisa menjawab akan keberadaan aplikasi untuk membantu memberikan informasi destinasi wisata.

Tabel 2. Hasil Jawaban Responden terhadap instrument pertanyaan

\begin{tabular}{cccccccc}
\hline & No & SS & S & RR & TS & STS & Total \\
\hline & A & C & D & E & F & G & H \\
\hline 1 & Pertanyaan 1 & 86 & 9 & 5 & 0 & 0 & $\mathbf{1 0 0}$ \\
2 & Pertanyaan 2 & 65 & 35 & 0 & 0 & 0 & $\mathbf{1 0 0}$ \\
3 & Pertanyaan 3 & 67 & 33 & 0 & 0 & 0 & $\mathbf{1 0 0}$ \\
4 & Pertanyaan 4 & 52 & 35 & 13 & 0 & 0 & $\mathbf{1 0 0}$ \\
5 & Pertanyaan 5 & 65 & 35 & 0 & 0 & 0 & $\mathbf{1 0 0}$ \\
6 & Pertanyaan 6 & 0 & 0 & 0 & 35 & 65 & $\mathbf{1 0 0}$ \\
7 & Pertanyaan 7 & 87 & 13 & 0 & 0 & 0 & $\mathbf{1 0 0}$ \\
8 & Pertanyaan 8 & 0 & 0 & 0 & 9 & 91 & $\mathbf{1 0 0}$ \\
9 & Pertanyaan 9 & 51 & 49 & 0 & 0 & 0 & $\mathbf{1 0 0}$ \\
10 & Pertanyaa 10 & 57 & 42 & 1 & 0 & 0 & $\mathbf{1 0 0}$ \\
\hline
\end{tabular}

Keterangan Tabel:

SS : Sangat Setuju

$\mathrm{S}$ : Setuju

RR : Ragu-ragu

TS : Tidak Setuju

STS : Sangat Tidak Setuju

Setelah instrument selesai diisi, maka diuji validitas kuesioner dilaukan pada aplikasi SPSS, dan didapatkan hasil sebagai seperti Gambar 11.

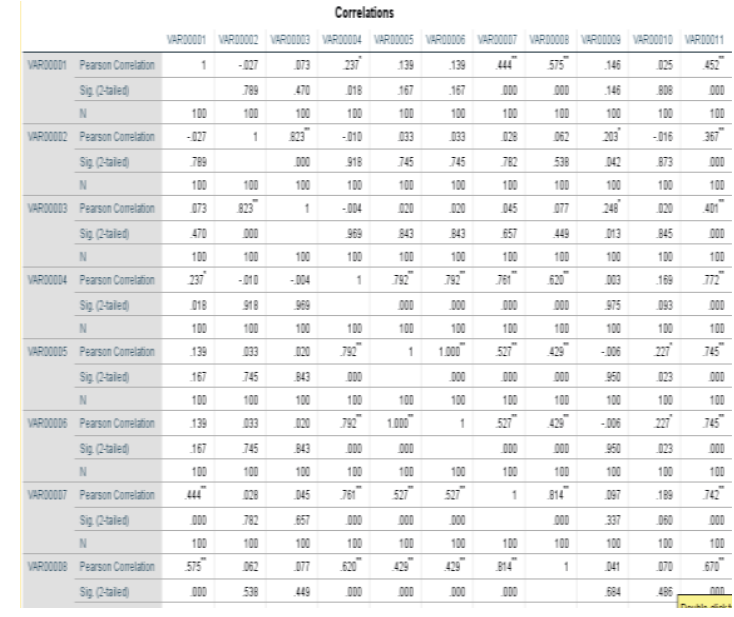

Gambar 11. Hasil validasi kuesioner menggunakan SPSS

Hasil diatas dapat dijabarkan seperti tabel dibawah ini

Tabel 3. Hasil Validasi kuesioner

\begin{tabular}{cccc}
\hline \multirow{2}{*}{ Pertanyaan } & r-tabel & r-hitung & Ket \\
\cline { 2 - 3 } 1 & signifikan $5 \%$ & & \\
\hline 2 & 0.196 & 0.452 & Valid \\
3 & 0.196 & 0.367 & Valid \\
4 & 0.196 & 0.401 & Valid \\
5 & 0.196 & 0.772 & Valid \\
6 & 0.196 & 0.745 & Valid \\
7 & 0.196 & 0.745 & Valid \\
8 & 0.196 & 0.742 & Valid \\
9 & 0.196 & 0.670 & Valid \\
10 & 0.196 & 0.397 & Valid \\
& 0.196 & 0.439 & Valid \\
\hline
\end{tabular}

Dari perhitungan validitas kuesioner yang dilakukan diperoleh hasil perhitungan bahwa variabel atau faktor dikatakan valid apabila mempunyai r-hitung lebih besar dari r-tabel. Uji validitas dilakukan dengan membandingkan nilai r-hitung (corrected item total correlation) dengan r-tabel. Jika nilai r-hitung lebih besar daripada r-tabel dan bernilai positif, maka butir pertanyaan per indikator tersebut dinyatakan valid (Hilabi dan Priati, 2018). Apabila sudah valid maka akan diberikan kepada responden yang diperkenalkan aplikasi sebelumnya. Kemudian hasilnya dicatat. Selanjutnya data hasil pengujian tersebut dianalisis, meliputi analisis kelima aspek usabillity, diantaranya yaitu learnability, eficiency, memorability, errors, dan satisfaction (Rahadi, 2014). Dari kuesioner yang telah diberikan kepada responden, data dianalisa menggunakan model skala likert. Skala likert merupakan suatu skala psikometrik yang paling banyak digunakan dalam riset berupa survey (Pudjoatmodjo dan Wijaya 2016).

Berikut hasil respon para responden terhadap pertanyaan pada kuesioner yang diberikan. Gambar diagram hasil untuk 1 pertanyaan. Dari sepuluh pertanyaan yang telah divalidasi pada kuesioner, maka 
disusun diagram hasil untuk masing, masing pertanyaan. Berikut adalah salah satu contoh hasil perpertanyaaan. Gambar berikut adalah diagram hasil untuk salah satu pertanyaan.

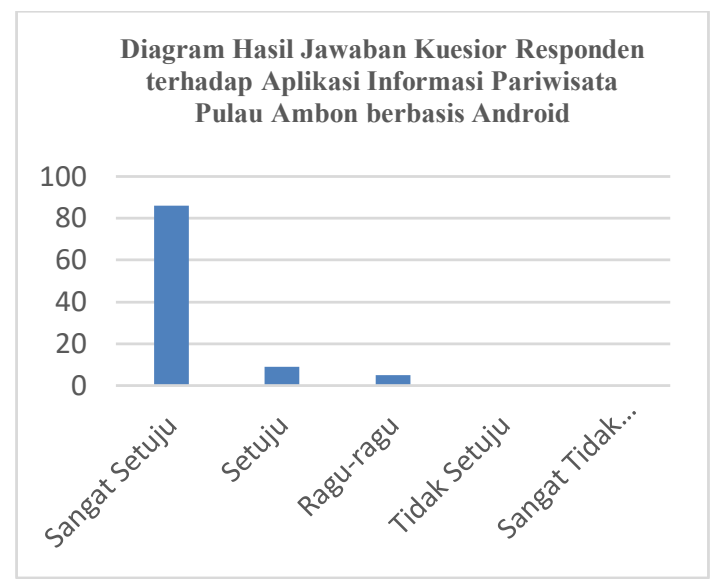

Gambar 12. Diagram Hasil Jawaban Untuk 1 pertanyaan

Contoh hasil respon terhadap masing-masinng pertanyaan dapat diwakilkan oleh gambar diagram diatas. Jadi apabila dijabarkan perpertanyaan, maka akan didapatkan sepuluh gambar diagram yang berisi respon terhadap masing-masing pertanyaan.

Diagram Hasil keseluruhan pertanyaan yang merupakan nilai kepuasaan responden terhadap aplikasi Sistem Informasi Wisata Pulau Ambon berbasis Android dapat dilihat seperti gambar dibawah ini.

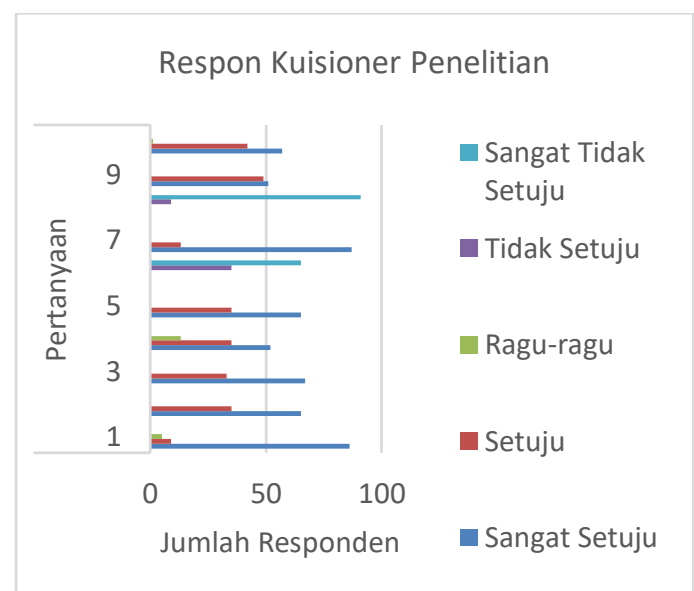

Gambar 13. Diagram Hasil Respon terhadap keseluruhan pertanyaan kuesioner

Dari diagram hasil terlihat bahwa sebagian besar responden setuju bahwa aplikasi mampu memenuhi learnability, eficiency, memorability, errors, dan satisfaction .

- Dari segi learnanility rata-rata pengguna mengatakan aplikasi gampang untuk dioperasikan dan tidak ada kebingungan dalam penggunaan beberapa istilah lokal pada aplikasi.

- Dari segi efficiency rata-rata user mengatakan bahwa fitur pada aplikasi yang didesain sudah cukup memenuhi kebutuhan informasi dan dapat diakses dengan mudah.

- Dari segi memorability rata-rata user bermaksud untuk merekomendasikan aplikasi kepada rekan, kenalan maupun orang-orang terdekat mereka.

- Dari segi errors, tidak ditemukan banyak kesalahan yang berarti, yang dapat mengganggu hasil informasi dan jalannya aplikasi.

- Dari segi satisfaction, hampir keseluruhan jawaban pertanyaan atas kuesioner menunjukkan kepuasan terhadap aplikasi yang dibuat.

Dari hasil tersebut dapat diartikan bahwa aplikasi yang dibuat cukup membantu pengguna dalam memperoleh informasi destinasi wisata di Pulau Ambon dan telah memenuhi aspek usability yang merupakan pengukuran kepuasan pemakai terhadap aplikasi dimaksud.

\section{KESIMPULAN DAN SARAN}

Pengujian usability dapat menentukan suatu aplikasi apakah sudah memenuhi kebutuhan pengguna dan tujuan dari rancangbangun aplikasi yang dimaksud. Secara peringkat kegunaan, pada umumnya suatu sistem lebih bergantung pada aspek kemudahan penggunaan daripada aspek fungsionalitas. (Dincklage, 2017)

Hasil pengujian usability terhadap aplikasi sistem informasi wisata Pulau Ambon berbasis Android mampu memberikan informasi tempat wisata, kegiatan wisata dan daftar kuliner yang bisa digunakan wisatawan untuk lebih memudahkan mereka dalam merencanakan tujuan wisata yang diinginkan. Hasil analisis terhadap responden juga menunjukkan bahwa aplikasi sudah cukup memenuhi kelima aspek usabillity, diantaranya yaitu learnability, eficiency, memorability, errors, dan satisfaction. Melalui pengujian usability dapat juga diperoleh analisis tentang hal-hal yang masih perlu diperbaiki dalam menyusun suatu aplikasi sistem informasi wisata untuk pengembangan lebih baik. Untuk pengembangan kedepan dapat disarankan suatu aplikasi yang terintegrasi dengan badan-badan yang berkaitan dengan pariwisata daerah di Pulau Ambon.

\section{DAFTAR PUSTAKA}

AMBON.GO.ID. 2019. Permudah Wisatawan Pemkot Ambon Bikin Ambon@Access. [online] Tersedia di:

$<$ https://www.ambon.go.id/permudahwisatawan-pemkot-ambon-bikin-ambonccess $>$ [Diakses tanggal 27 Desember 2019]

ANTARAMALUKU.COM. 2018. Pemkot Ambon Luncurkan Sistem Informasi Kreatif Pariwisata. [online]. Tersedia di:

$<$ https://ambon.antaranews.com/berita/47813/pe mkot-ambon-luncurkan-sistem-informasi- 
1068 Jurnal Teknologi Informasi dan Ilmu Komputer (JTIIK), Vol. 7, No. 5, Oktober 2020, hlm. 1061-1068

kreatif-pariwisata $>$ [Diakses tanggal 28 Desember 2019.]

BALAPOUR A., SABHERWAL R. 2017. Usability of Apps and Websites: A Meta Regression Study. Twenty-third Americas Conference on Information Systems, Boston.

BATMETAN J.R., MAMONTO J., LEGESAN H., SAGAI Z. 2018. Pengukuran Usability Sistem Operasi Android Menggunakan Use Questionaire di Universitas Negeri Manado. Program studi Pendidikan Teknologi Informasi dan Komunikasi, Universitas Negeri Manado.

DINCKLAGE V.F., SUCHODOLSKI K., LICHTNER G., FRIESDORF W., PODTSCHASKE B., RAGALLER M. 2017. Investigation of the Usability of Computerized Critical Care Information Systems in Germany. Journal of Intensive Care Medicine 1-11

FERDINANDUS. A.M, SURYANINGSIH I.A. 2014. Studi Pengembangan Wisata Bahari Untuk Meningkatkan Kunjungan WIsatawan di Pantai Natsepa Kota Ambon Provinsi Maluku. Jurnal Destinasi Pariwisata, Vol. 2 No. 2.

HILABI S.S. DAN PRIATI. 2018. Analisis Kepuasan Pengguna Terhadap Layanan Aplikasi Media Sosial WhatsApp Mobile Online. Buana Ilmu. Vol.3 No.1.

KADIR ABDUL. 2013. From Zero To Pro. Jakarta : Andi Publisher.

NIRMALA B.M.S, LIANDANA M. 2017. Analisi Usability Pada Aplikasi Mobile Trip Planner Etourism Pariwisata di Bali. Jurnal Nasional Pendidikan Teknik Informatika. Vol. 6 No.3.

PRESSMAN, R. S. 2012. Rekayasa Perangkat Lunak Pendekatan Praktisi Edisi 7. Penerbit Andi, Yogyakarta.

PUDJOATMODJO, B. DAN WIJAYA, R. 2016. Tes Kegunaan (Usability Testing) Pada Aplikasi Kepegawaian Dengan Menggunakan System Usability Scale. Seminar Nasional Teknologi Informasi dan Multimedia. 37-42.

RAHADI D.R. 2014. Pengukuran Usability Sistem Menggunakan Use Questionnaire Pada Aplikasi Android Interface pengguna Android didasarkan pada manipulasi langsung menggunakan masukan sentuh yang serupa dengan tindakan di dunia nyata, seperti menggesek ( swiping ), mengetuk. Jurnal Sistem Inf. Vol. 6, no. 1,

RINI NURAINI. 2015. Desain Algorithma Operasi Perkalian Matriks Menggunakan Metode Flowchart. Jurnal Teknik Komputer AMIK BSI. Vol 1. No. 1.

SUARAKARYA.ID. 2019. Disparbud Kota Ambon Berupaya Mewujudkan Program Visit Ambon2020. [online] Tersedia di: $<\underline{\text { https://www.suarakarya.id/detail/85700/Disp }}$ arbud-Kota-Ambon-Berupaya-Mewujudkan-
Program-Visit-Ambon-2020> tanggal 3 September 2019]

[Diakses

SUDARMA M.2019. Persepsi Wisatawan Terhadap Efektifitas E-Kios Destinasi Pariwisata Bali. Teknologi Elektro. Vol. 8 No.1.

V. FUSPITA V. VATRESIA A. ANDRESWARI D. 2014. Sistem Pendukung Keputusan Pemilihan Restoran Di Kota Bengkulu Dengan Metode Simple Additive Weighting (Saw) Berbasis Sistem Operasi Android. J. Rekursif. Vol. 2. No. 1. 45-52. 